\title{
SENSITIVITY ANALYSIS OF VARIOUS COST ELEMENTS IN FLEXIBLE PAVEMENT DESIGN
}

\section{SEPTEMBER 1972 - NUMBER 28}

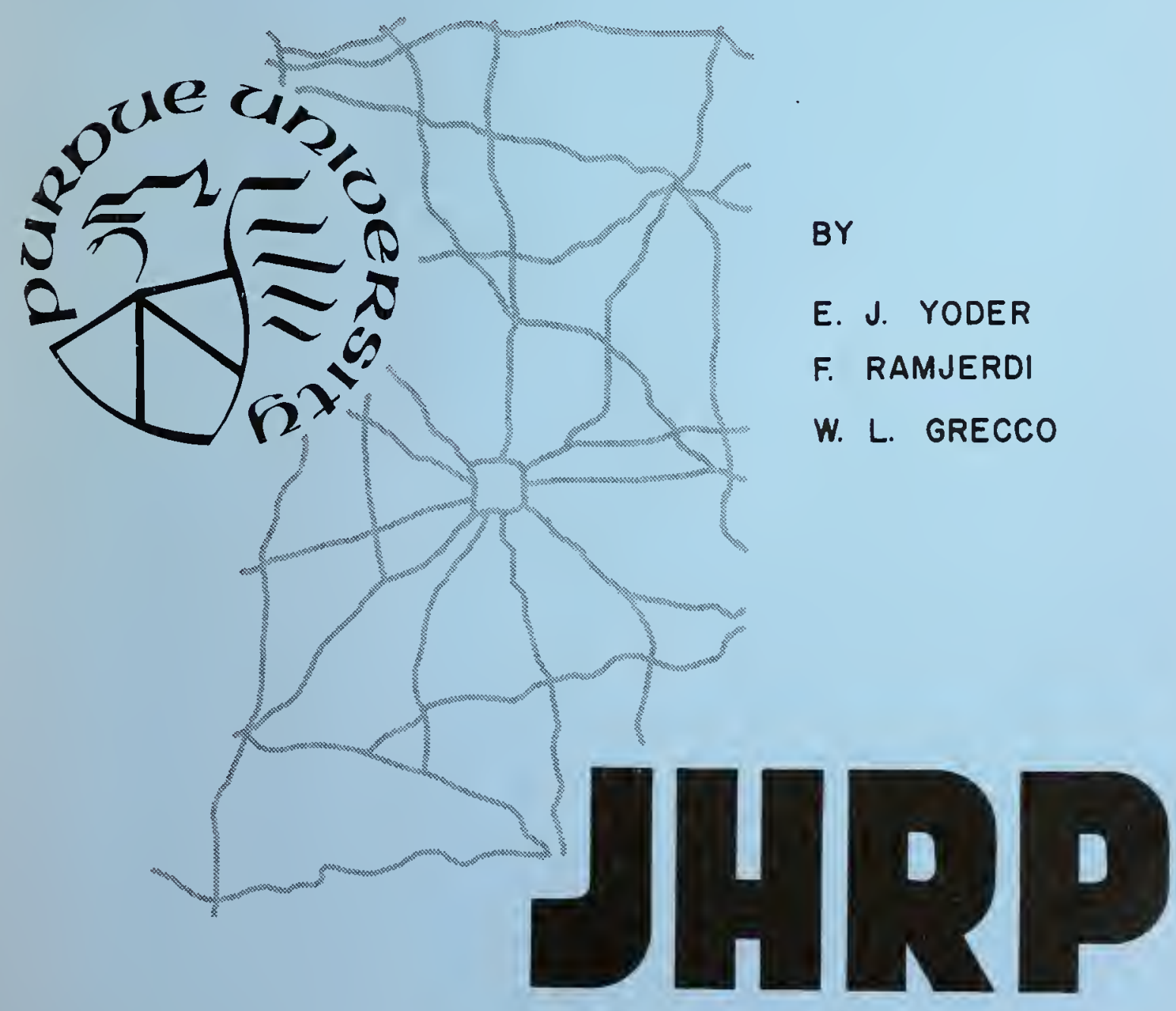

JOINT HIGHWAY RESEARCH PROJECT PURDUE UNIVERSITY AND

INDIANA STATE HIGHWAY COMMISSION 



\section{Technica1 Paper \\ SENSITIVITY ANALYSIS OF VARIOUS COST ELEMENTS IN FLEXIBLE PAVEMENT DESIGN}

T0: J. F. McLaughlin, Director Joint Highway Research Project

FROM: H. L. Michael, Associate Director Joint Highway Research Project
September 7, 1972

Project: $\quad \mathrm{C}-36-52 \mathrm{H}$

File: $6-20-8$

The attached Technical Paper "Sensitivity Analysis of Various Cost Elements in Flexible Pavement Design" has been authored by E. J. Yoder, Farideh Ramjerdi and W. L. Grecco of our staff. The paper will be presented at the Third International Conference on the Structural Design of Asphalt Pavements", September 11-15, 1972, in London, Eng 1 and.

The paper is an outgrowth of the research study conducted by Miss Ramjerdi and reported to the Board last year. The paper is presented to the Board for approval of publication.

Respectfully submitted,

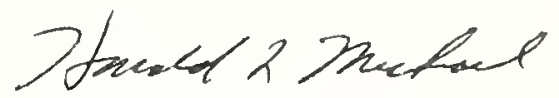

Harold L. Michael

Associate Director

HLM : ms

cc: W. L. Dolch

R. L. Eskew

W. H. Goetz

M. J. Gutzwiller

G. K. Ha1lock

R. H. Harre11
M. L. Hayes

C. W. Love 11

G. W. Marks

R. D. Miles

J. W. Miller

G. T. Satterly
C. F. Scholer

M. B. Scott

J A. Spooner

N. W. Steinkamp

H. R. J. Wa1sh

E. J. Yoder 
Digitized by the Internet Archive in 2011 with funding from

LYRASIS members and Sloan Foundation; Indiana Department of Transportation 
Technical Paper

SENSITIVITY ANALYSIS OF VARIOUS COST ELEMENTS IN FLEXIBLE PAVEMENT DESIGN

\author{
by \\ Eldon J. Yoder \\ Professor of Highway Engineering \\ Farideh Ramjerdi \\ Research Assistant \\ and \\ William L. Grecco \\ Professor of Civil Engineering \\ Joint Highway Research Project \\ Project No.: C $-36-52 \mathrm{H}$ \\ File No.: 6-20-8 \\ Conducted By \\ Joint Highway Research Project \\ Engineering Experiment Station \\ Purdue University \\ In Cooperation with \\ Indiana State Highway Commission
}

Purdue University

West Lafayette, Indiana

September 7, 1972 


\section{SENSITIVITY ANALYSIS OF VARIOUS COST \\ ELEMENTS IN FLEXIBLE PAVEMENT DESIGN}

\section{ABSTRACT}

This paper presents a method for predicting the optimum initial service life and optimum periods of resurfacing for flexible pavements. The method is based on consideration of total pavement costs including the cost of initial construction, routine maintenance and major maintenance and increased road user costs resulting from the maintenance operations.

Standard economic analyses techniques were used for determining the average annual cost of alternate designs. A modification of the Radzikowski model was used for estimating routine maintenance cost of flexible highway pavements. The pavement design method developed by the Corps of Engineers was utilized in estimating initial design as well as required major maintenance (resurfacing). A method was developed which presented an estimation of road user cost due to maintenance and resurfacing operations. 
Variables evaluated in this paper included (I) subgrade type, (2) initial traffic volume, (3) rate of traffic growth, and (4) rate of interest on the investment. Solutions were made for both 2-lane and divided 4-lane highways.

The results of the study are presented in the form of graphs which indicate the initial design period which results in least cost for combinations of the variables given.

\section{INTRODUCTION}

The function of a highway pavement is to provide a riding surface that adequately serves the demands of the road user with an acceptable level of performance. A great amount of research has bcen conducted into principles for the structural design of highway pavements. Many methods, based on an estimation of the strongth of the pavement components coupled with an estimation of the amount of traffic which will use the pavement, are available to the engineer which enables him to determine the thickness reguirements for flexible pavements. In general, a finite service life is assumed and then resurfacing of the pavement is planned for the end of the analysis period.

The ultimate aim of the highway engineer responsible for the planning and design of pavements is to provide a pavement which will maintain specified serviceability throughout the pavement's life, and to provide the highway user with the best possible 
scrvice at the lowest cost. There are two primary elements of cost which must be considered, (I) the average annual cost of the highway facility, including both initial and maintenance costs, and (2) the average annual cost of operating motor vehicles on the pavement structure.

A major decision that the design engineer must make is that regarding service life, and intervals at which major maintenance should be planned. There are little factual data in the literature which can provide the design engineer with a method for making decisions relative to the initial service life, and the optimum interval that should be considered for major maintenance.

The purpose of this research was to develop a method for predicting the optimum initial service life and the optimum periods of resurfacing for flexible pavements, and evaluate the sensitivity of variables involved in these decisions.

The formula recommended by Baldock ( 1$)^{*}$ was used in this study for determining the annual costs and comparison of alternate designs. The pavement design method developed by the Corps of Engineers and presented by Turnbull, Foster, and Ahlvin (2) formed the basis for this analysis. The equation developed by ulbricht (3) was used to arrive at the total cumulative number of equivalent 18kip single axle applications in terms of average daily traffic.

* Numbers in parentheses refer to references cited in the Bibliography 
Variables included in this research include: (1) subgraae Eyou, (2) initial traffic volume, (3) rate of traffic growth, and (4) ratc of intcrest. Solutions were made for: 2-lane highways and 4-lane divided highways, and for analysis periods of 20 and 40 years. The effects of highway user costs resulting from maintonance and resurfacing operations were analyzed.

COST MODEL COMPONENTS

The model determined optimum initial design service life for Elcrible pavements surfaces as a function of design variables. Design variables included: initial yearly equivalent 18-kip, single axle load applications; annual growth rate of traffic; analysis period; road users costs due to maintenance and resurfacing operations; interest rate; subgrade CBR percentage; and either 2-Izne or divided 4-lane roadways. Sensitivity analyses were performed on the basis of the changes on the design-decision variables noted above as initial design service life of surface. Values are given in the Appendix (see Figures A-1 to A-8). The values which provided the Figures ( $A-1$ to $A-8)$ are the result of many plots of the cost percentages as shown typically as figure 1. The low points of each curve are used for the range of values $f$ or each of the independent variables. Figure 1 is based on a percentage of the highest average annual cost per mile (usually at two ycars as initial design service life and a CBR of two percent). 


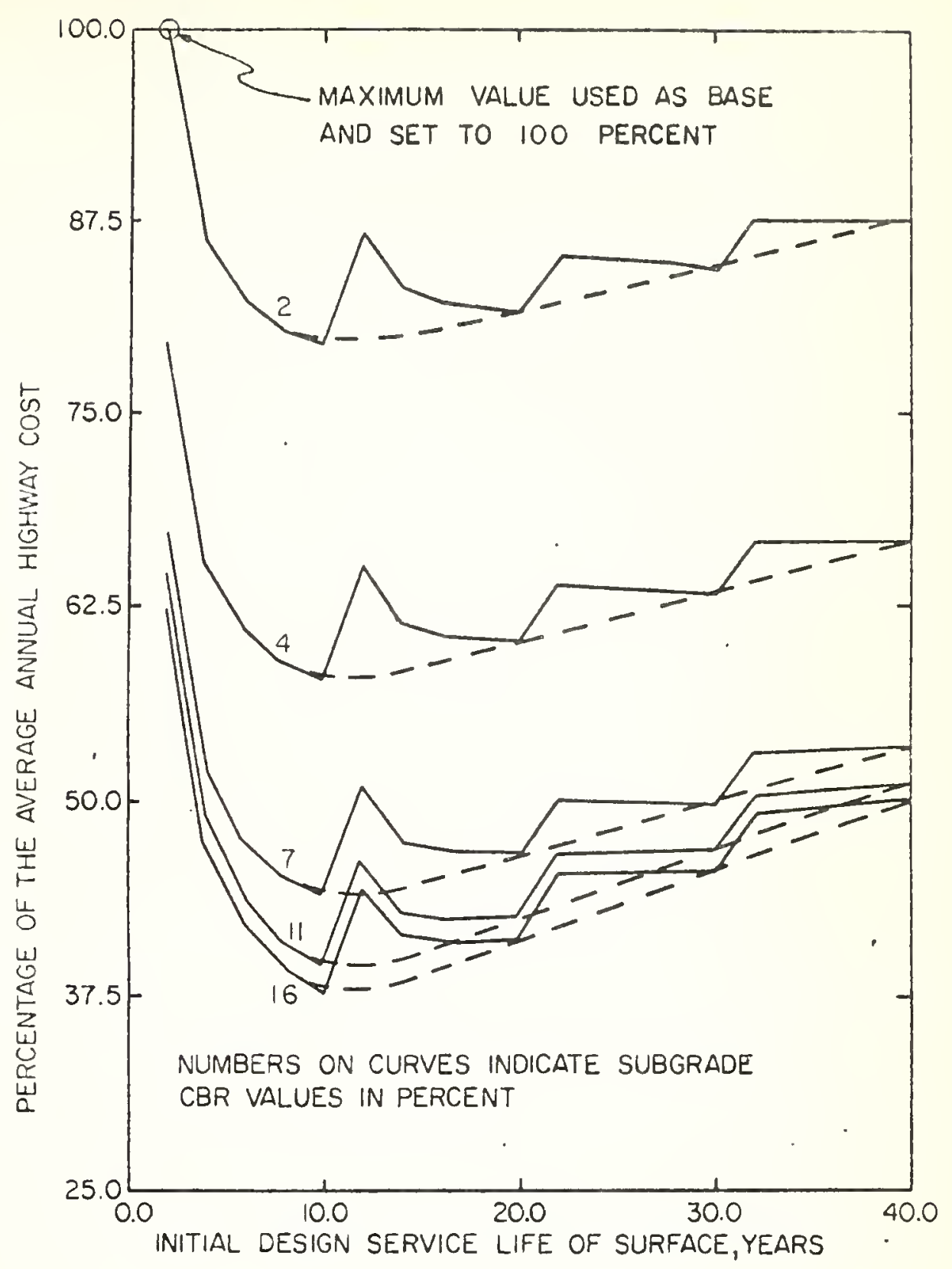

FIG. I A TYPICAL PLOT PRODUCED BY THE CALCOMP PLOTTER 
The cost cquation was a modification of that proposed by Balciock and is as follows:

$$
\begin{aligned}
& C=C R F_{n}\left[A+E_{I}\left(P W F_{n I}\right)+R E_{1}\left(P W E_{n I}\right)\right. \\
& +E_{2}\left(P W F_{n 2}\right)+R E_{2}\left(P W F_{n 2}\right)+\ldots . . \\
& +E_{m}\left(P W F_{n m}\right)+R E_{m}\left(P W F_{n m}\right) \\
& -\left(I-\frac{Y}{X}\right)\left(E_{m}\right)\left(P W F_{n m}\right) \\
& \left.+\sum_{i=1}^{n} M_{i}\left(P W F_{i}\right)+\sum_{i=1}^{n} R M_{i}\left(P W F_{i}\right)\right]
\end{aligned}
$$

where

$C$ = average annual cost per mile of highway,

$C R F_{n}=$ capital recovery factor for an analysis of $n$ years and for a given interest rate,

f. = initial construction cost per mile of pavement,

$\mathrm{E}_{1}=$ first resurfacing cost per mile,

$n_{1}=$ years of service life of initial pavement surface, $\mathrm{PWF}=$ present worth factor for $\mathrm{n}_{1}, \mathrm{n}_{2}, \ldots$ or $\mathrm{n}_{\mathrm{m}}$ years for a given interest rate,

$\mathrm{RE}_{1}=$ road user cost due to the first resurfacing per mile, $\mathrm{L}_{2}=$ second resurfacing cost per mile,

$n_{2}=$ number of years after construction to year when second resurfacing is placed, 
$\mathrm{KE}_{2}=$ road user cost due to the second resurfacing per mile,

$n_{m}=$ number of years after construction to year when nth $^{\text {th }}$ resurfacing is placed,

$R E_{m}=$ road user cost due to the $\mathrm{m}^{\text {th }}$ resurfacing per mile,

$Y=$ number of years from time of last resurfacing to end of analysis period,

$X=$ estimated life of last resurfacing in years,

$M_{i}=$ maintenance cost during the $i^{\text {th }}$ year after construction per mile,

$\mathrm{PWF}_{i}=$ present worth factor for $i$ years and for a given rate of interest,

$R M_{i}=$ road user cost due to the maintenance operation during $i^{\text {th }}$ year per mile.

Easic components of Equation 1 are (a) initial construction cost, (b) resurfacing costs, (c) maintenance costs, (d) road user costs due to maintenance and resurfacing operations, (e) interest rate, (f) analysis period, and (g) service life of initial pavement surface, and service lives of the resurfacings.

The major purpose of this study was to solve equation $I$ for a variety of conditions to determine the service life of the initial pavement surface and the service lives of the resurfacings, that result in the lowest average annual cost.

Structural Design Procedure

The structural design procedure used in this study was a modification pavement design method developed by the corps of 
Lregineers and presented by Turnbull, Foster, and Ahlvin. It was assumcd in this study that the required thickness of pavement for one 18,000-ib single axle load application is equal to zero. Therefore, the general form of design curves takes the following form:

$$
D=C \log W
$$

where

$D=$ pavement thickness in inches,

$W=$ total number of EAL applications during the design life,

$C=$ coefficient of the equation which is a function of the CBR of subgrade.

Utilizing the CBR design curves from the previous reference, an oquation was developed for ease of computer simulation and Equation 2 takes the following fo $\mathrm{m}$ :

$$
D=\left(7.8844-8.07181 \log C B R-2.20335 \log ^{2} C B R\right) \log W
$$

where

$D=$ pavement thickness, inches,

$C B R=$ subgrade $C B R$ value in percent,

$W^{T}=$ the cumulative number of EAL applications.

In this study minimum thickness of base and subbase layers were assumed to be 4 and 6 inches respectively. A CBR value of 30 percent was adopted for the subbase material.

\section{Minimum Recuired Thickness of Surface}

An evaluation was made of minimum thickness requirements proposea by the Texas Highway Department (4). Regression analysis 
male on the rexas method provided equations for the three tyres of basc matcrial. Only Equation 4 which is used for Grade 1 is shown here:

$$
\mathrm{ds}=1.60649-1.78145 \log w+0.31092 \log ^{2} w
$$

where

$$
\begin{aligned}
\mathrm{ds}= & \text { minimum required thickness of asphaltic concrete } \\
& \text { surface, inches, } \\
W= & \text { total EAL application.. }
\end{aligned}
$$

On the basis of this analysis, an absolute minimum thickness of surface was set at 1.9 inches.

\section{Equivalent Fixle Load Applications}

The equation developed by Ulbricht (3) for Indiana was adopted for this study. This equation takes the following form:

$$
\begin{aligned}
& W=(F)(V) \\
& V=365(A D T)\left[\frac{(I+J)^{Y}-I}{\ell \Omega(I+J)}\right] \\
& W=365(F)(A D T)\left[\frac{(I-J)^{Y}-I}{\ell n(I+J)}\right]
\end{aligned}
$$

where

$W=$ the cumulative number of EAL applications,

$F=$ the equivalence coefficient,

$V=$ number of vehicles,

$A D r=$ the initial average daily traffic in one direction,

$\bar{y}=$ the annual traffic growth rate,

$Y=$ the number of years for which cumulative number of EAL applications is to be estimated. 
Ulbricht, in his study, classified Indiana highways into tirrec classes by traffic weight distribution, and estimated $F$, the cquivalence coefficient for each class. An $F$ value of 0.16 was adopted for this study.

\section{Recuired Pavement Thickness as a Function of Time}

The required thickness of pavement and the minimum reguired surface thickness can be obtained as a function of time by substituting Equation 5 for $W$ in Equations 3 and 4 respectively.

\section{Resurfacing Costs}

Resurfacing costs were computed on the basis of thickness of layers placed at each stage, and the unit price of the resurfacing material. The extra surface thickness (major resurfacing or major maintenance) required at any instant of time is equal to the difference between assumed initial design thickness and the required thickness as would be determined on the basis of traffic up to the time of resurfacing. The period of resurfacing was taken as the value of the initial design service life of surface. It was assumed in this study that if a resurface was to be placed at intervals greater than 10 years, a seal coat layer was placed on the pavement at the end of 10 years in lieu of the major resurface.

\section{Routine Maintenance Costs}

The model developed by Radzikowski(5) was used in this study, since surface maintenance expenditures were of major interest. rost of the other models investigated included methods for estimating shoulder and right-of-way maintenance. 
Eour basic factors are considered in the model developed by $\therefore u d z i j o w s k i$ for the prediction of maintenance expenditure. These تactors arc: (1) traffic on the section measured in vehicles per day for two lanes of pavement, (2) type of subgrade soil, (3) thickness of the surface, and (4) thickness of the base and/or subbase. Each of these factors were related to maintenance effort index numiers.

Lquations 6 through 11 developed through stepwise regression anaiyses rclate maintenance effort index to the four basic factors cescribed. These equations had $R^{2}$ values above 0.9990 .

$$
\begin{aligned}
& I_{d_{s}}=14.42857-2.41501\left(d_{s}\right)+0.10187\left(d_{s}^{2}\right) \\
& I_{a_{b s}}=5.71265-0.95354\left(d_{b}+d_{s b}\right)+0.04042\left(d_{b}+d_{s b}\right)^{2} \\
& I_{s}=9.938-6.436\left(\log c B R_{s g}\right) \\
& I_{x}=\left(\frac{I}{1000}\right) x . \\
& I=I_{d}+I_{d_{b}}+I_{s}+I_{x} \\
& V_{=}=279.19395-3.46509\left(I^{2}\right)+0.33537\left(I^{3}\right)
\end{aligned}
$$

where

$$
\begin{aligned}
& I_{d_{s}}=\text { maintenance effort index for surface thickness, } \\
& a_{s}=\text { surface thickness in inches, }
\end{aligned}
$$




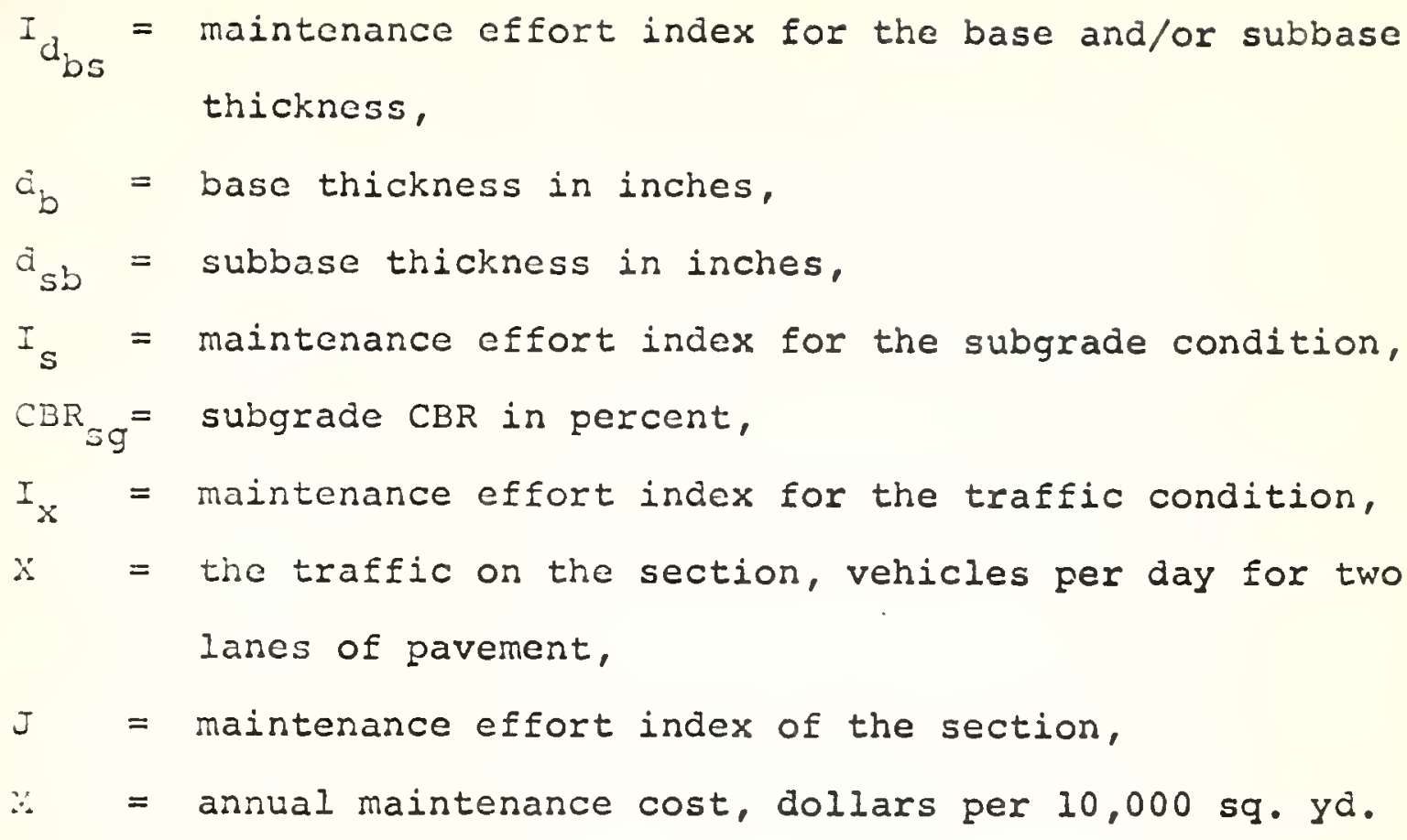

Unit Cost of Paving Materials

Unit cost of bituminous surface, base, subbase, surface treatmont, and sealing materials adopted for this study were based on the average unit bid price, obtained from the Indiana state Highway Commission and are as follows:

Eituminous surface

base

subbase

sirface treatment

soal coat
3743.238

1415.969

1048.178

3000.953

2173.441 dollars/mile/lane/inch of thickness

"1

I1

dollars/mile/lane/layer

" $"$ "

\section{Roac User Cost Due to Maintenance and Resurfacing Operations}

Por the purpose of this study, road user costs due to maintenance and resurfacing operations were assumed to be extra costs to 
road uscrs because of maintenance operations. These extra costs wcre estimated on the basis of relationships between road user cost and the average speed of traffic in the traffic flow. fccident costs resulting from maintenance and resurfacing operations were not considered.

In this study, it was assumed that specifications would limit the extent of lane closure for each resurfacing operation to $1 / 2$ mile with a duration of closure of 8 hours. For sealing operations, the length of the lane closure would be 1 mile with a duration of closure of 8 hours. This latter amount was also used for routine maintenance operation. It was also assumed that each section was ciosed once a year for routine maintenance operation. The shoulder would be used as a traffic lane when one lane was closed on the 2-lane highway. No attempt was made to optimize the extent and the duration of the closure in relation to the traffic.

Eeiationship Between the Average Speed of Traffic and Traffic Flow

In this study, the highway types considered were 2-lane and 4-iane divided highways. Relationships between the average speed of traffic and vehicular flow in passenger car equivalents (p.c.e.'s) during both normal conditions and with one lane closed were estabiished using data from the Highway Capacity Manual (6). An average factor used for conversion of one truck amounted to 3.58 passenger car equivalents.

For both of the highway types (2-lane and 4-lane) a lane width of $12 \mathrm{ft}$. and a shoulder width of $8 \mathrm{ft}$. were used. The percentage 
of trucks in the traffic stream was assumed to be 14 percent of the total. The highways were assumed to be in level terrain, When one lane was closed for maintenance or resurfacing operations, the distance from traffic lane edge to obstruction was set at zero. Nonlinear weighted regression analysis was used to arrive at a relationship between the average speed of traffic and the traffic flow. The general form of the model used in these analyses was:

$$
v=B_{0}+B_{1}(v)+B_{2}\left(v^{2}\right)+B_{3}\left(v^{3}\right)
$$

where

$V=$ the average speed of traffic in miles per hour, $v=$ the traffic flow in passenger car equivalents per hour, $B_{0}, B_{1}, B_{2}$, and $B_{3}=$ the parameters of the model.

Using the equation form noted above, $B_{0}$ represents the value of the average speed of traffic as the traffic flow approaches zero and $\mathrm{B}_{1}$ can be calculated as a function of $\mathrm{B}_{2}, \mathrm{~B}_{3}$ and $\mathrm{v}$. The parameters of $B_{2}$ and $B_{3}$ were estimated using the nonlinear weighted regression analysis. Because the resulting equations were internal to the computer program for forecasting road users costs, no attempt was made to report them.

Relationship Between the Road User Cost and the Average Speed of Traffic

The components of the road user cost are the operating expenditures for fuel, oil, tires, and vehicle maintenance and repair, ana allowances for depreciation, time, and comfort and convenience. The Writio Red Book provides information which relates road user costs 
for passenger cars to the average speed of traffic (7). This information is available for 2-lane and divided highways, under Erce, normal, and restricted operations, and four different gradient classes. A gradient class of 3-5 percent was adopted for this study.

\section{Other Road User Costs}

There is an extra cost associated with vehicle stops, besides Enat of constant speed operation. This extra cost depends on the approach specd. There are data available in the AASHO Red Book (7) that relate the extra cost per vehicle stop to the standing delay poilod for different approaching speeds. A cost trend adjustment factor of 1.67 was applied to the data available in the AASHO Red Eook to convert these costs from 1959 to 1969.

A correction was also included for the extra turning maneuver rcquired due to the lane closure. For conditions of curved alinement a correction is made by increasing tangent costs in accordance with a correction factor that depends on the sharpness of the curve and superelevation ( 7 ). As different alternates had the same alinement no correction was made, except for the extra turning maneuver, due to lane closure.

It was assumed that the traffic changes lane in a distance of 200 ft.. Tharefore, the degree of curvature for this maneuver was approximately $4^{\circ}$. The superelevation was obviously zero.

Equations for computing the correction factor for one-half and cae mile closures as a function of average traffic speed wore acvoloped. 
ANALYSIS

The models noted earlier were utilized to calculate average annul costs of 2-lane highways and divided 4-lane highways. Programs were written in FORTRAN IV computer programming language. Crilcoilp routines and plotter were used to produce the necessary plots of data.

Average annual costs of highways were computed for initial design service lives of the surfaces ranging from two years up to the end of the analysis period. The initial design service life of surface which resulted in the lowest value of the average annual cost was accepted as the best alternate.

A sensitivity analysis on subsoil condition, traffic, interest rate, and analysis period was made using the following values: for subgrade $C B R$ values of $2,4,7,11$, and 16 percent; initial average daily traffic values of 10, 50, 100, 1000, 2000, 5000, and 10,000 ADT; annual traffic growth rates of $2,6,10$, and 14 percent; interest rates 6,13 , and 20 percent; and analysis periods of 20 arci 40 years. The problem was also solved with and without the consideration of the road users costs due to lane closures.

The initial construction cost increased as the initial design service life was increased. There were also sudden rises in this cost item, when base and/or subbase were required (minimum base anci subbase thicknesses adopted in this study were 4.0 and 6.0 inches respectively). The routine maintenance expenditure was a 
decreasing function of the initial design service life of surface. This expenditure was computed on a yearly basis. Of the factors in the model used for predicting this cost item, thicknesses of surfacc, base and subbase were subject to change as initial design life of surface was changed.

The thickness factor increased as the initial design service life of surface increased. This resulted in a decrease in routine maintenance expenditure as the initial design service life of surface was increased. The resurfacing expenditure also decreased as the initial design service life increased. Therefore, the greater the initial design service life of surface, the less thickress had to be provided to maintain the pavement function throughout the remaining analysis period.

Cost of sealing was an increasing function of the initial design service life of surface in this problem. The resurfacing interval was always equal to the initial design service life of the surface. It was assumed that if a resurface was to be placed at intervals of time greater than 10 years, a seal coat layer should be placed on the pavement at the end of 10 years. Therefore, up to initial design service life of surface of 10 years, no sealing was required. For initial design service life of surface of IO years to 20 years, one seal coat layer was needed, and for an initial design service life of surface of 20 to 40 years, two seal coat layers were required, etc. 
This study was conducted with and without the consideration of road users costs due to lane closures as a component of the average annual cost of highway. Obviously, these costs items increased as the frequency of lane closures increased. Road user costs due to routine maintenance were the same for all alternates, as it was assumed that each section was closed once a year for this purpose. Road user cost due to major maintenance cecreased as the initial design service life of surface (which was also equal to the period of resurfacing) was increased. Howcver, road user cost due to sealing increased as initial design service life of surface was increased since, as explained earlier, the number of times that sealings were required increased as the initial design service life was increased.

For any given initial value of average daily traffic, rate of traffic growth, and rate of interest, the average annual highway cost was the highest in the case of a subgrade CBR value of 2 percent and initial design service life of 2 years of all the average annual highway costs for the adopted $C B R$ values and other initial design service lives of surface. Therefore, average annual highway costs were computed as a percentage of this highest value (2 percent CBR and two year interval) for different CBR values and other initial design service lives average annual cost. The computer plotter was so utilized to produce plots of this percentage of cost of surface, as a function of the initial design service life of surface, and for the subgrade $C B R$ values adopted for this study. 
Plots of cost were produced in the same manner for the two and four lane highways, with and without the consideration of road uscr cost due to lane closure and for analysis periods of 20 and 40 years; the adopted values of average daily traffic; arnual traffic rates of growth and rates of interest.

Figure 1 shows a typical plot produced by the CALCOMP plotter, showing the percentage of the average annual cost of highway to be the appropriate average annual cost of the highway sor a subgrade CBR value of 2 percent, and initial design service life of surface of 2 years. The sample given in Figure 1 is for a divided 4-lane highway with an average daily traffic value of 2000 RDI; annual rate of traffic growth of 2 percent; rate of intcrest of 6 percent; analysis period of 40 years; and with the consideration of the road users costs due to lane closures.

The function relating the average annual cost of highway to the initial design service life of surface is a one of sequence, since the average annual cost of highway is defined only for the czact time of the initial design service life of surface. There werc sudden rises and falls in the average annual cost of highway as the initial design service life of surface was increased. This occurred because of fluctuations in components of the average annial cost of highway with the increase of the initial design scrvicc life of surface as described in the previous paragraph. ricucfore the produced plots represent the average annual cost of hichways as a price-wise linear function of the initial design service life of surface. 
Decause of the complexity of analyzing the factors that culece the rises and falls, a smooth curve was passed through the lower points of the produced plots. The ordinate values of Figure 1 reprosent the percentage value when comparing the annual cost of the highway to its appropriate (and maximum) average annual cost $O E$ highwaylfor a subgrade $C B R$ value of 2 percent and initial design service life of surface of 2 years). The dashed smooth curves on Eigure I illustrate this assumption through visual inspection. riat is, the appropriate initial design service life of surface rcsults in minimum values of average annual cost. The sensitivity analysis included the following: effects. of the length of analysis period; consideration of road user costs due to lane closures, subgracie CBR, initial yearly equivalent 18-kip, single-axle load applications; annual rate of traffic gorwth; and interest rate.

\section{RESULTS OF ANALYSIS}

The initial design service life factor which resulted in the minimum average annual cost of 2-lane highway and 4-lane divided highway can be determined through visual inspection of the modified piots. Figures $A-1$ through $A-8$ in the Appenaix show the optimum initial design service life of pavement surface as a function of the initial yearly EAL for the 2-lane highway. These facts were cictcrmined with and without consideration of road users costs resulting from lane closures, different interest rates, subgrade CDE values, traffic rate of growth, analysis periods of 20 and 40 yours, and for 2-lane and divided 4-lane highways. Although computitions werc made for the divided 4-lane highway analysis, the 
plots (though different) are not included as they show very similar rciationships. The following summarizes the results noted from the inspection of Figures $A-1$ through $A-8$ :

1. The optimum initial design service life remained constant as the initial yearly EAL increased up to some maximum value. However, beyond this value the service Iife increased as a constant rate. The value of the initial yearly EAL at which the initial design service life changes from a constant value to an increasing function of the initial yearly EAL was defined as the critical value of the initial yearly EAL.

The value of the critical initial yearly EAL depended upon the consideration of road user costs due to lane closures, interest rate, traffic rate of growth, subgrade $C B R$ value, and the analysis period. This critical value decreased as the traffic rate of growth increased, and as the interest rate decreased. The critical value of the initial yearly EAL decreased as the subgrade CBR decreased and as the analysis period was increased. The rate of increase in the initial design service Iife beyond the critical value of the initial yearly EAL depended on the rate of interest, subgrade CBR value, analysis period, and on the traffic rate of growth. The rate of increase in the initial design service life lessened as the rate of interest increased. 
Although it can not be illustrated the divided 4-lane highway critical values of the initial EAL are higher than those of a 2-lane highway; and the rate of increase in the optimum initial design service life of a 4-lane highway is lower than that of a 2-lane highway. This is particularly evident for the higher CBR values.

2. The optimum initial design service life decreased as the interest rate increased. For the very low subgrade $C B R$ values, this was true for the entire range of the initial yearly EAI. However, for higher subgrade CBR values the optimum initial design service life was lower for higher interest rates, generally beyond the critical values of the initial yearly EAL.

3. Analysis with consideration of the road user costs due to lane closures resulted in the same or an increase of the optimum initial design service life over the total range of the initial yearly EAL for low subgrade CBR values but over the range beyond the critical value of the initial yearly EAL for higher subgrade CBR values, an increase was indicated. The difference between the optimum initial design service life when road user costs due to lane closures were considered, and when road users costs due to lane closures were not considered was as 
high as 2 years over the range before the critical initial design service life. Beyond this range the difference was as high as 10 years for an analysis period of 20 years and even higher for the analysis period of 40 years.

Beyond the critical value of the initial yearly EAI, the difference between the initial design service Iife with the consideration of the road user costs due to lane closures was greater for a divided 4-lane highway than for a 2-lane highway.

4. When road users costs due to lane closures were considered at higher subgrade $C B R$ values, the optimum design service life was approximately the same (about 10 years). In the range beyond the critical value of the initial yearly EAL, the initial design service life decreased as subgrade $C B R$ value increased.

5. In the range beyond the critical value of the initial yearly EAL, the difference between the optimum initial design service life when road user costs due to lane closures were considered and when they were not considered, decreased when the rate of interest increased.

6. The optimum initial design service life in the range lower than the critical value of the initial yearly EAI was constant and approached 10 years for both 2-lane highways and divided 4-lane highways and for either of 
the analysis periods of 20 and 40 years. The critical value of the initial yearly EAL was always lower for 2-lane highways than for the divided 4-lane highway for same values of all variables. The optimum initial design service life was lower for divided 4-lane highways and for analysis period of 20 years.

\section{BIBIIOGRAPHY}

1. Baldock, R. H., "Determination of the Annual Cost of High"viys", Highway Research Board, Highway Research Board Record 1.0.12, 1963.

2. Cumbull, W. J., Foster, C. R., and Ahlvin, R. G., "Design of Plexible pavements Considering Mixed Loads and Traffic volume", Proceedings, lst International Conference on Structural Design of Asphalt Pavements, University of Hichigan, 1962 .

3. Ulbricht, E. P., A Method for Comparing Alternate Pavement Designs, MSCE Thesis, Purdue University, 1967.

4. Foxas Highway Department, Test Method Tex-117-E, 1964.

5. Racizikowski, H. A., "Report of the Committee on Maintenance Costs", Mighway Research Board Bulletin No. 155, 1966.

6. Tighway Research Board, "Highway Capacity Manual", Highway Iosearch Board Special Report No. 87, 1965.

7. Rnerican Association of State Highway Officials, Road User Eencfit Analyses for Highway Improvements, 1960. 
APPENDIX 


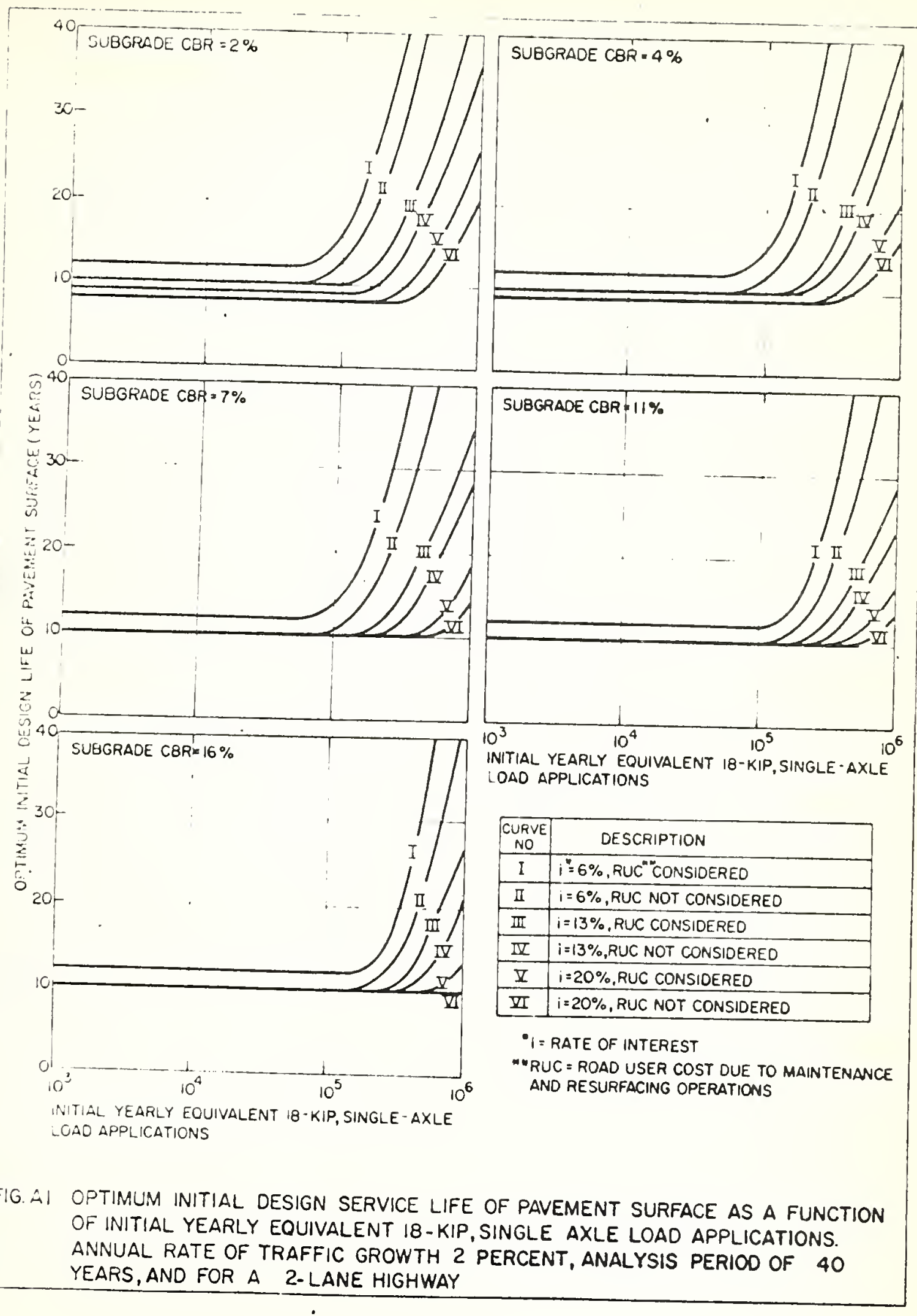




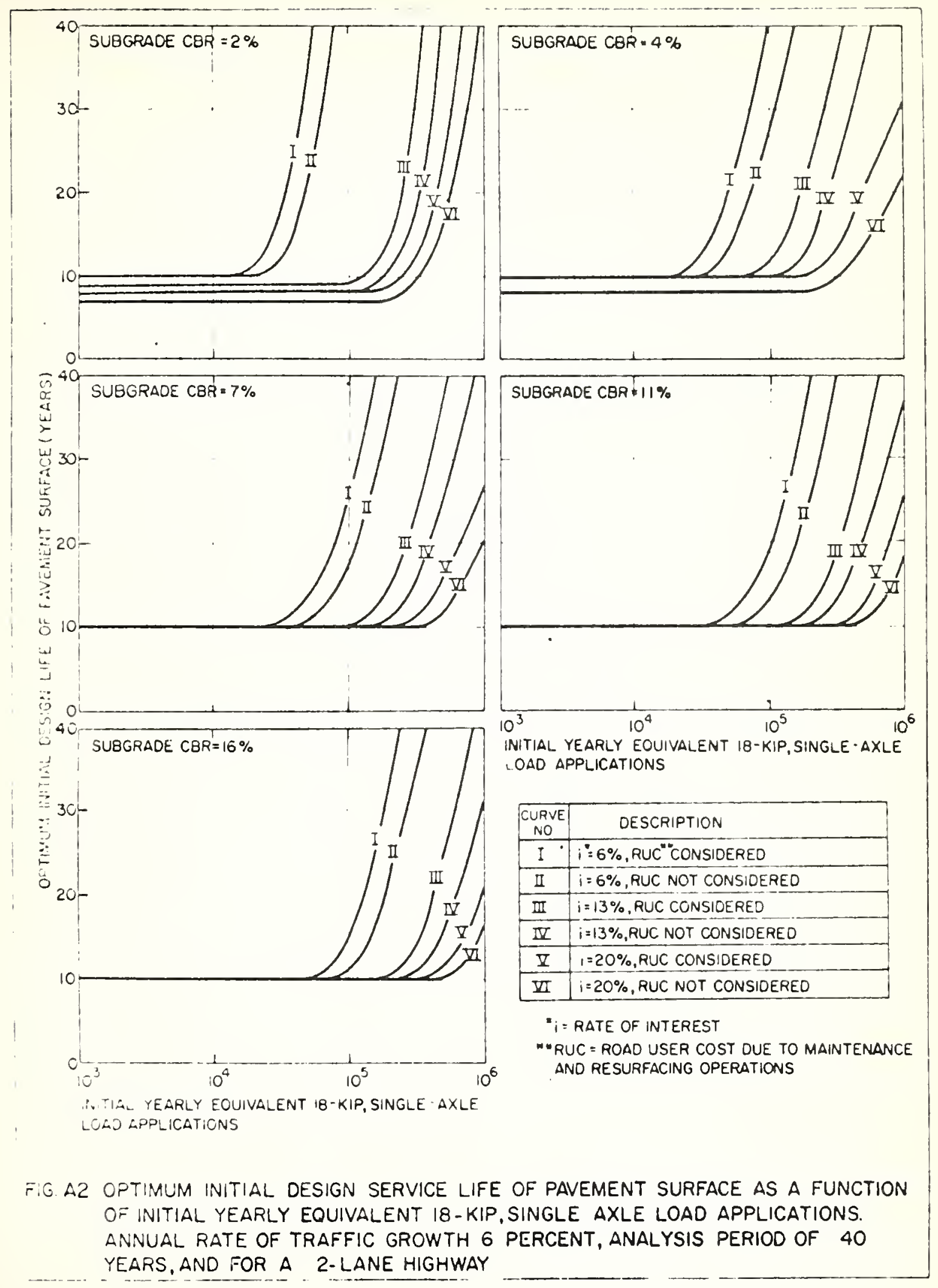



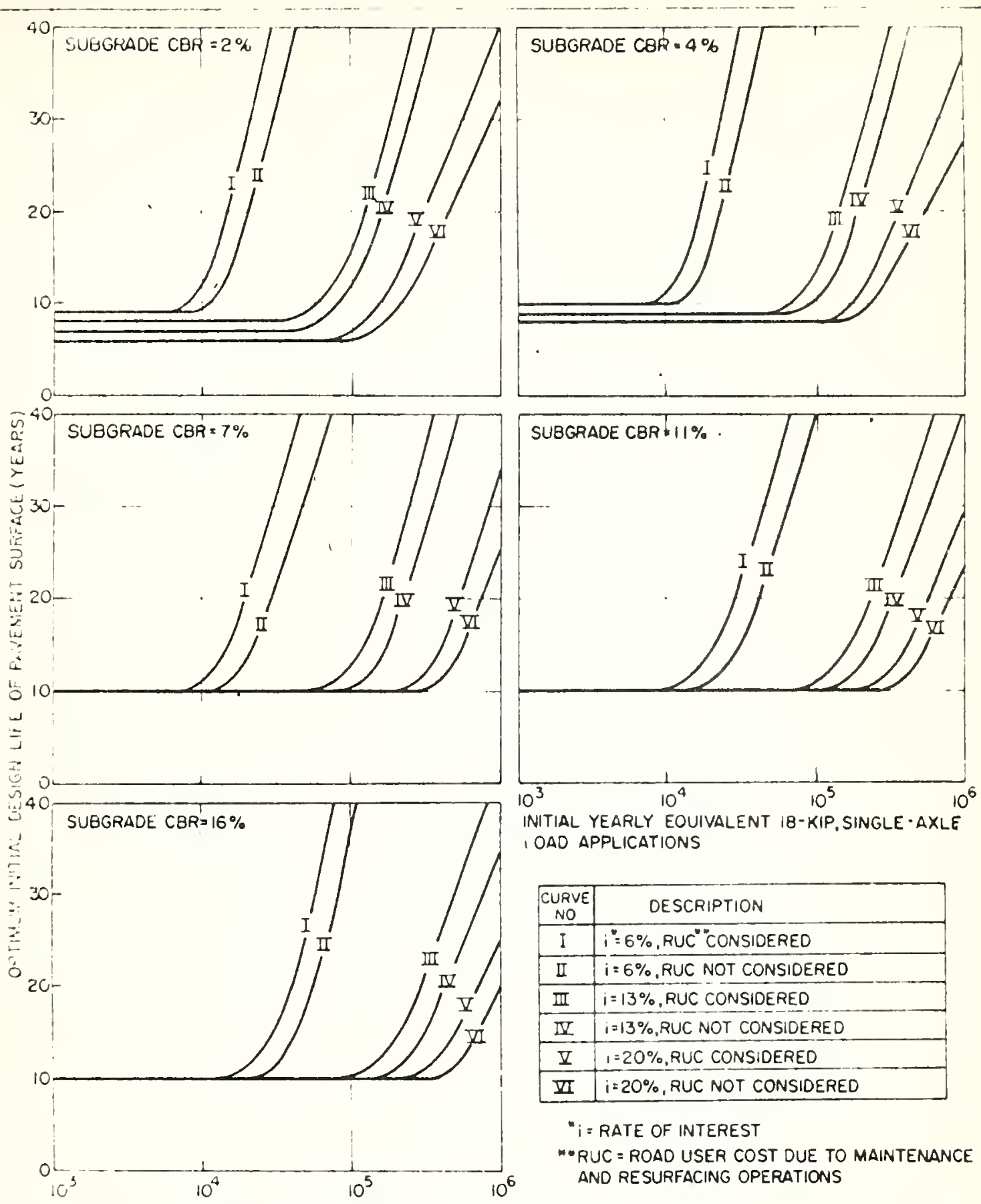

INITIAL YEARLY EOUIVALENT 18 -KIP, SINGLE-AXLE IOAD APPLICATIONS

\begin{tabular}{|c|c|}
\hline $\begin{array}{c}\text { CURVE } \\
\text { NO }\end{array}$ & \multicolumn{1}{|c|}{ DESCRIPTION } \\
\hline I & $i=6 \%$, RUC" CONSIDERED \\
\hline II & $i=6 \%$, RUC NOT CONSIDERED \\
\hline II & $i=13 \%$, RUC CONSIOERED \\
\hline IV & $i=13 \%$, RUC NOT CONSIOERED \\
\hline I & $i=20 \%$, RUC CONSIOERED \\
\hline III & $i=20 \%$, RUC NOT CONSIDERED \\
\hline
\end{tabular}

" $i=$ RATE OF INTEREST

* RUC $=$ ROAD USER COST DUE TO MAINTENANCE AND RESURFACING OPERATIONS

INITIAL YEARLY EOUIVALENT 18-KIP, SINGLE" AXLE LOAJ APPLICATIONS

FIG.A3 OPTIMUM INITIAL DESIGN SERVICE LIFE OF PAVEMENT SURFACE AS A FUNCTION OF INITIAL YEARLY EQUIVALENT I8-KIP, SINGLE AXLE LOAD APPLICATIONS. LNNUAL RATE OF TRAFFIC GROWTHIO PERCENT, ANALYSIS PERIOD OF 40 YEARS, AND FOR A 2 - LANE HIGHWAY 


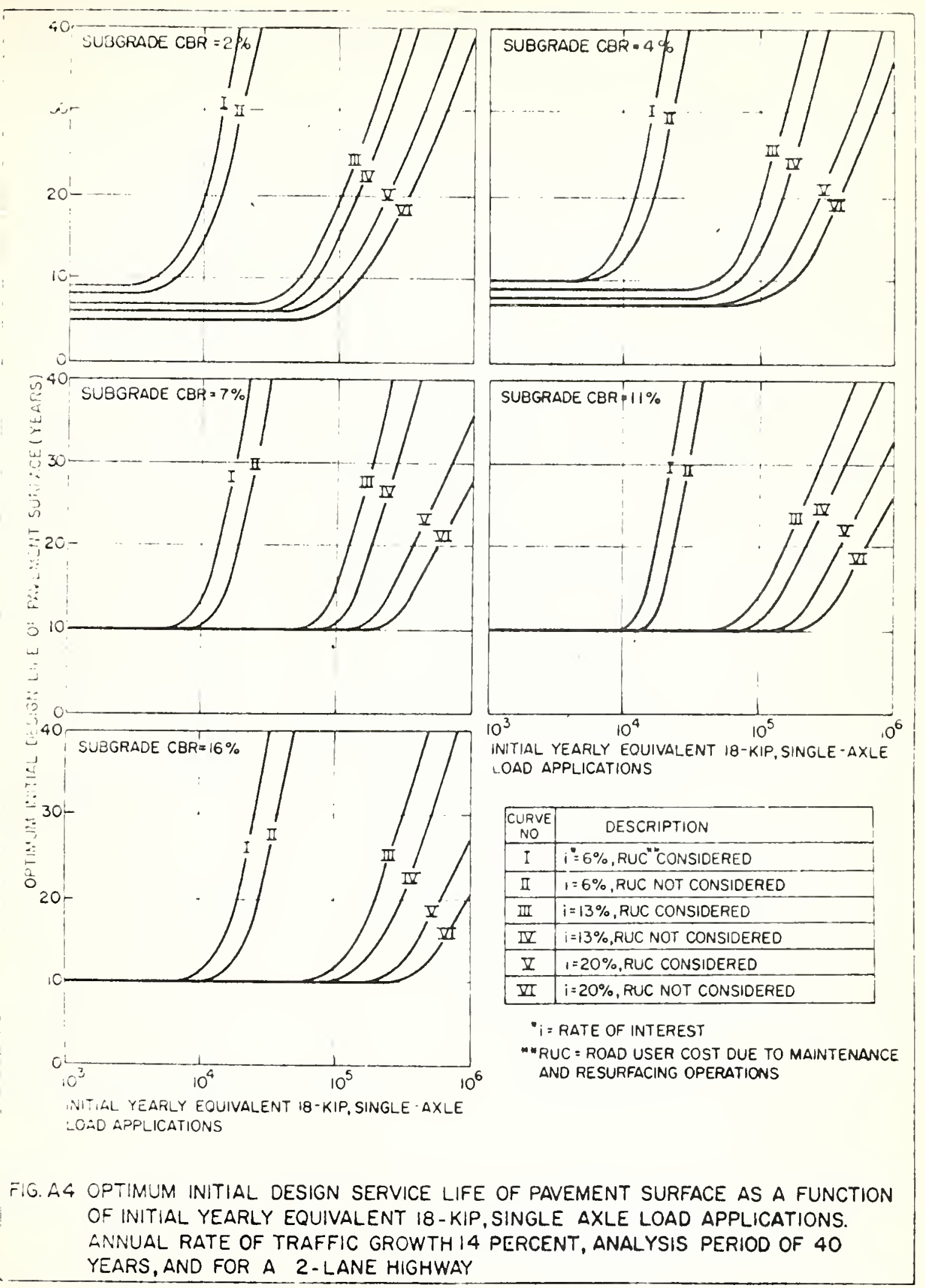




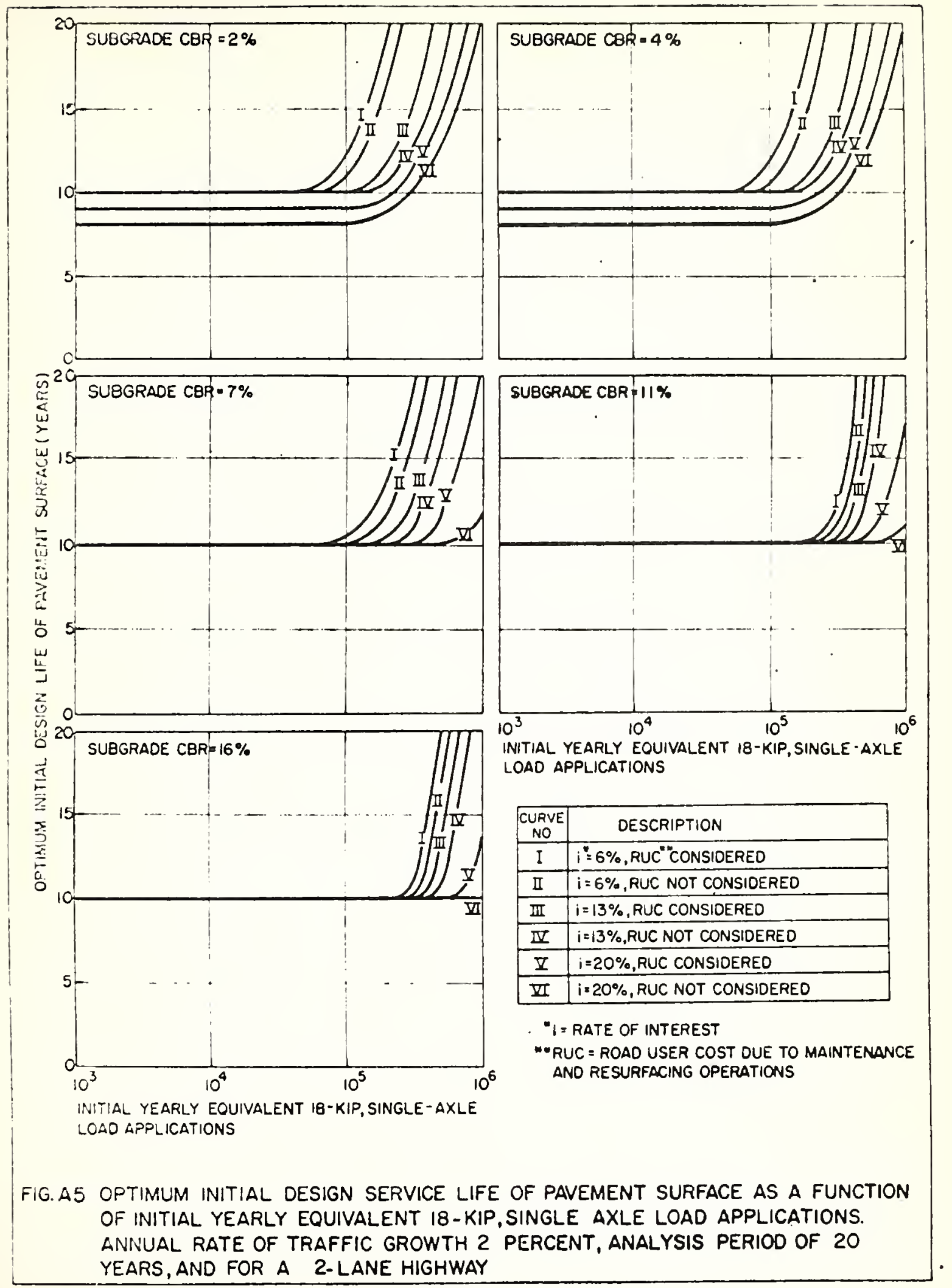




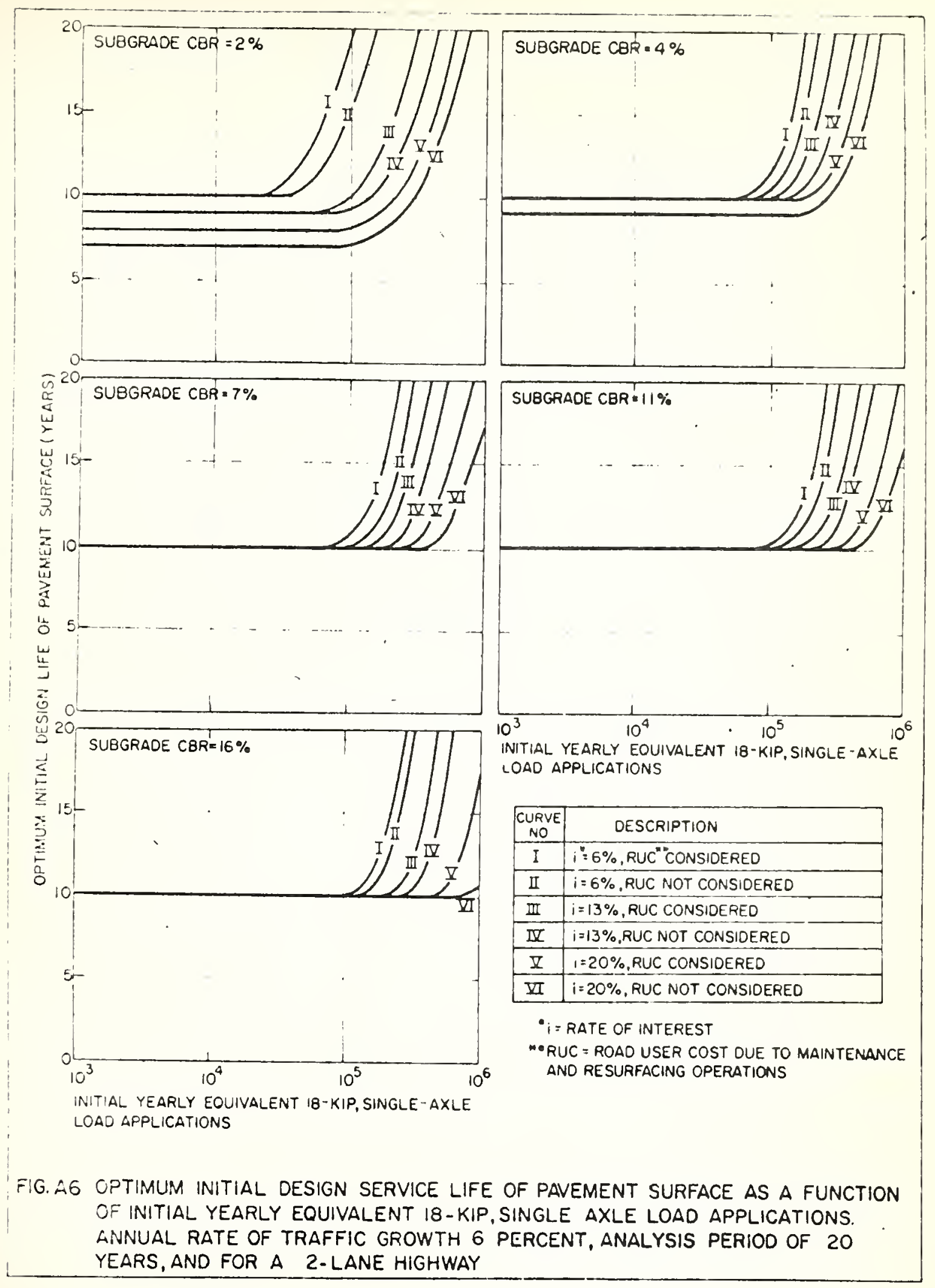




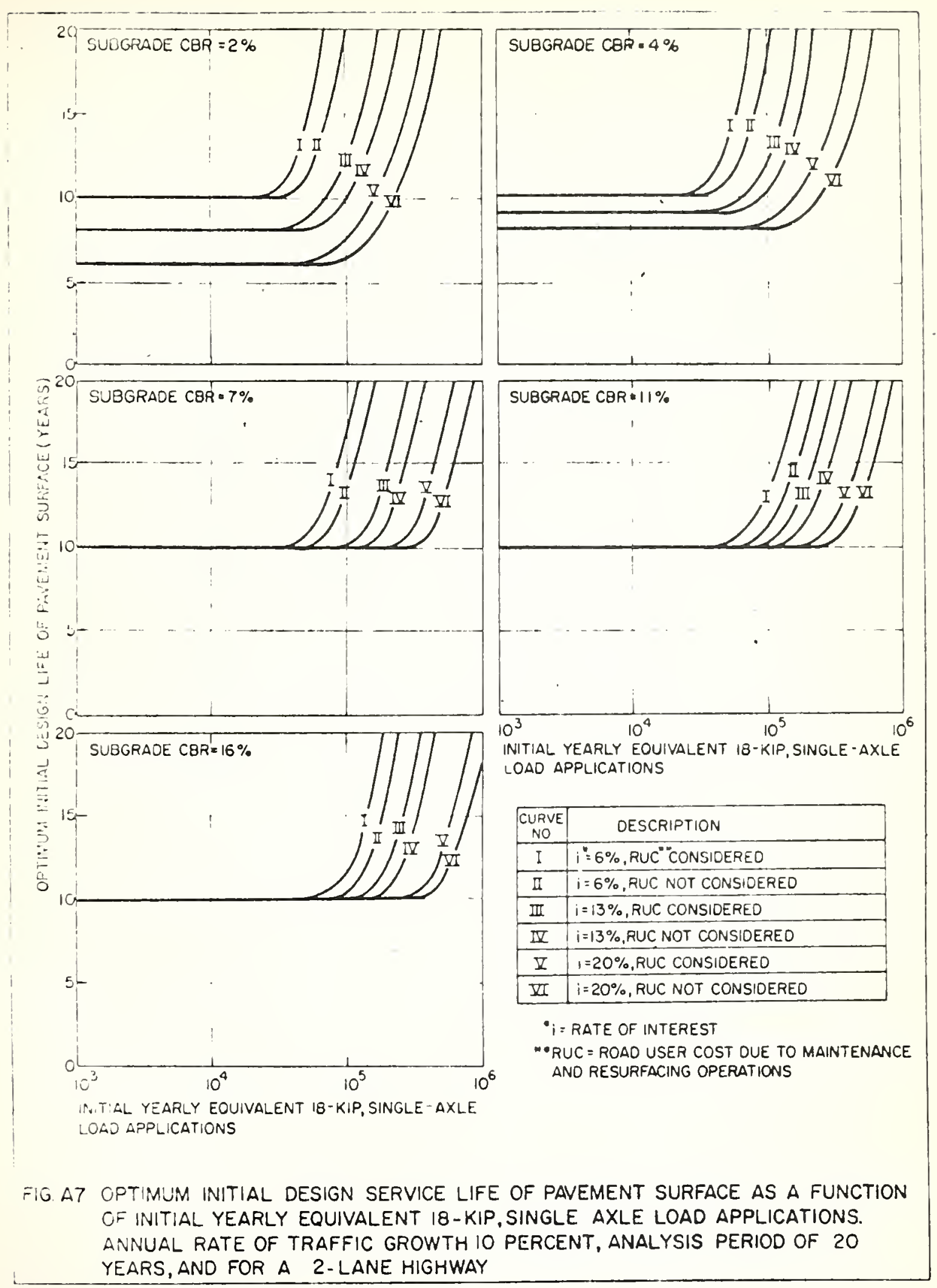




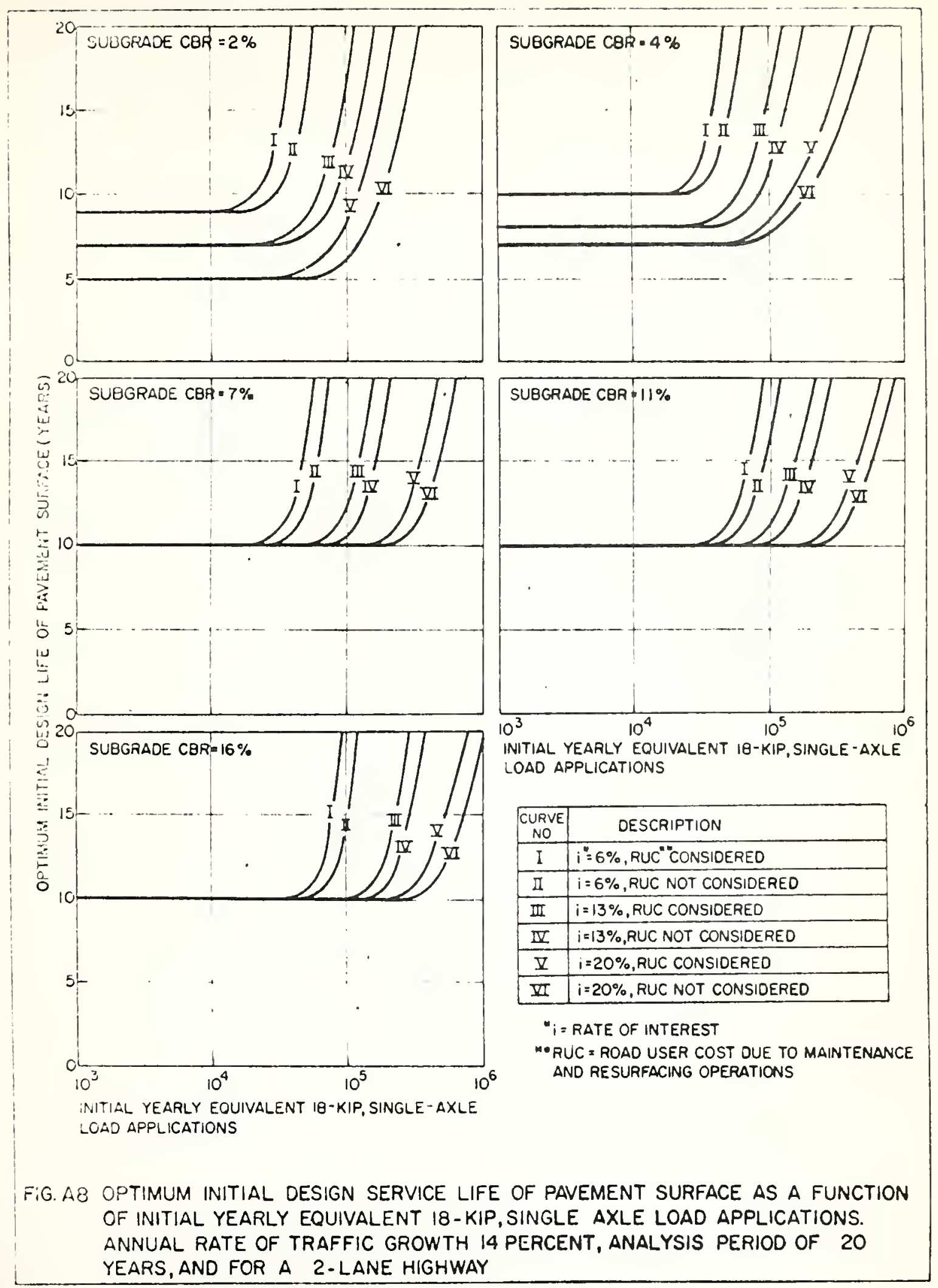



